\title{
Bathymetric distribution of some benthic and benthopelagic species attracted to baited cameras and traps in the deep eastern Mediterranean
}

\author{
E. G. Jones ${ }^{1,4, *}$, A. Tselepides ${ }^{2}$, P. M. Bagley ${ }^{1}$, M. A. Collins ${ }^{1,3}$, I. G. Priede ${ }^{1}$ \\ ${ }^{1}$ University of Aberdeen, OceanLab, Newburgh, Aberdeen, AB41 6AA, Scotland, United Kingdom \\ ${ }^{2}$ Institute of Marine Biology of Crete, PO Box 2214, Heraklion 71003, Crete, Greece \\ ${ }^{3}$ British Antarctic Survey, High Cross, Madingley Road, Cambridge CB3 0ET, United Kingdom \\ ${ }^{4}$ Present address: Fisheries Research Services, Marine Laboratory, PO Box 101, Victoria Road, Aberdeen AB11 9DB, \\ Scotland, United Kingdom
}

\begin{abstract}
A series of baited camera and trap experiments in the eastern Mediterranean Sea between 1500 and $4264 \mathrm{~m}$ depth attracted a variety of opportunistic scavengers, with species composition changing with increasing depth. At the shallower stations (1500 to $1800 \mathrm{~m}$ ), decapod crustaceans and fishes, dominated by elasmobranchs such as Hexanchus griseus, were attracted to and actively consumed the bait. Some of these species were observed at depths exceeding their previously reported ranges. This was believed to be a result of the absence of deep-water scavengers from the adjacent Atlantic due to dispersal barriers and elevated temperatures at depth. The diversity of bait-attending fauna declined with increasing depth. Elasmobranchs were not observed below $2500 \mathrm{~m}$, and below $4000 \mathrm{~m}$ only the caridean shrimp Acanthephyra eximia and the macrourid Chalinura mediterranea were present; at this latter depth, bait consumption was negligible. This shift in species composition was reflected in changes in first arrival times. Increasing first arrival times of $H$. griseus suggested a decline in relative abundance from 1500 to $2500 \mathrm{~m}$, whilst those of $C$. mediterranea indicated an increase in relative abundance from 1800 to $4264 \mathrm{~m}$.
\end{abstract}

KEY WORDS: Baited camera · Autonomous lander $\cdot$ Hexanchus griseus $\cdot$ Chalinura mediterranea

\section{INTRODUCTION}

The deep-sea environment is characterised by distinct vertical gradients of pressure, light, temperature and food availability (Carney et al. 1983, Gage \& Tyler 1991). As a result of these gradients, depth-related changes in benthic and benthopelagic fauna have frequently been observed in trawl catches (Merrett \& Marshall 1981, Hecker 1990, Gordon \& Bergstad 1992, Fujita et al. 1995, Moranta et al. 1998). An alternative sampling technique, using free-fall baited traps and cameras, has also demonstrated both depth-related and latitudinal changes in relative abundance and diversity of opportunistic scavenging megafauna (Desbruyérès et al. 1985, Priede et al. 1994, Thurston et al. 1995, Collins et al. 1999, Yau et al. 2002). In some of these studies, the relative abundance of species attracted was inferred from differences in the time taken for the first individual to reach the baited camera (Priede \& Merrett 1996, 1998). Similar methods have proved successful in shallower habitats for estimating the abundance of predatory reef fishes (Ellis \& DeMartini 1995, Willis \& Babcock 2000, Willis et al. 2000). Some important assumptions are necessary: that individuals are evenly dispersed across the sea floor; that they are mobile; and that the dispersal time of the odour plume is invariant between stations. The technique has its biases (see Willis \& Babcock 2000), but offers a relatively low-cost method of sampling mobile fauna at great depths, as well as providing additional information on habitat and behaviour. 
Very little is known of the ecology of deep demersal fauna in the eastern Mediterranean. These waters constitute a unique environment characterised by unusually warm temperatures of 13 to $14^{\circ} \mathrm{C}$, and extreme oligotrophy (Dugdale \& Wilkerson 1988, Ignatiades 1998, Psarra et al. 2000). A sharp gradient of availability of organic matter exists, related to depth and distance from the shore (Tselepides \& Eleftheriou 1992, Karakassis \& Eleftheriou 1998, Tselepides et al. 2000a). Compared to other areas of similar latitude and depth, there is a general scarcity of deep-sea benthos, from microbes and meiofauna (Soyer 1985, Danovaro et al. 1995) to macrofauna (Fredj \& Laubier 1985, Tselepides \& Eleftheriou 1992, Tselepides et al. 2000b). The lack of food, in combination with high temperatures inducing high metabolic rates, is believed to be the main reason for the impoverished benthic fauna (Pérès 1982). Some limited deep-water trawling in this region has confirmed the scarcity of ichthyofauna (Tortonese 1960, Klausewitz 1989), and baited trap deployments have not yielded the familiar scavengers, such as lysianassid amphipods (Christiansen 1989, Albertelli et al. 1992).

In this paper we describe the results of a series of baited camera and trap experiments carried out between 34 and $36.5^{\circ} \mathrm{N}$ and 25 and $28.5^{\circ} \mathrm{E}$ during the course of 2 research cruises. The results were analysed in terms of composition and distribution of benthic and benthopelagic bait-attracted species between regions, seasons and in relation to the depth gradient. In addition to simple presence and absence information, the times of first arrival of species attracted to the camera

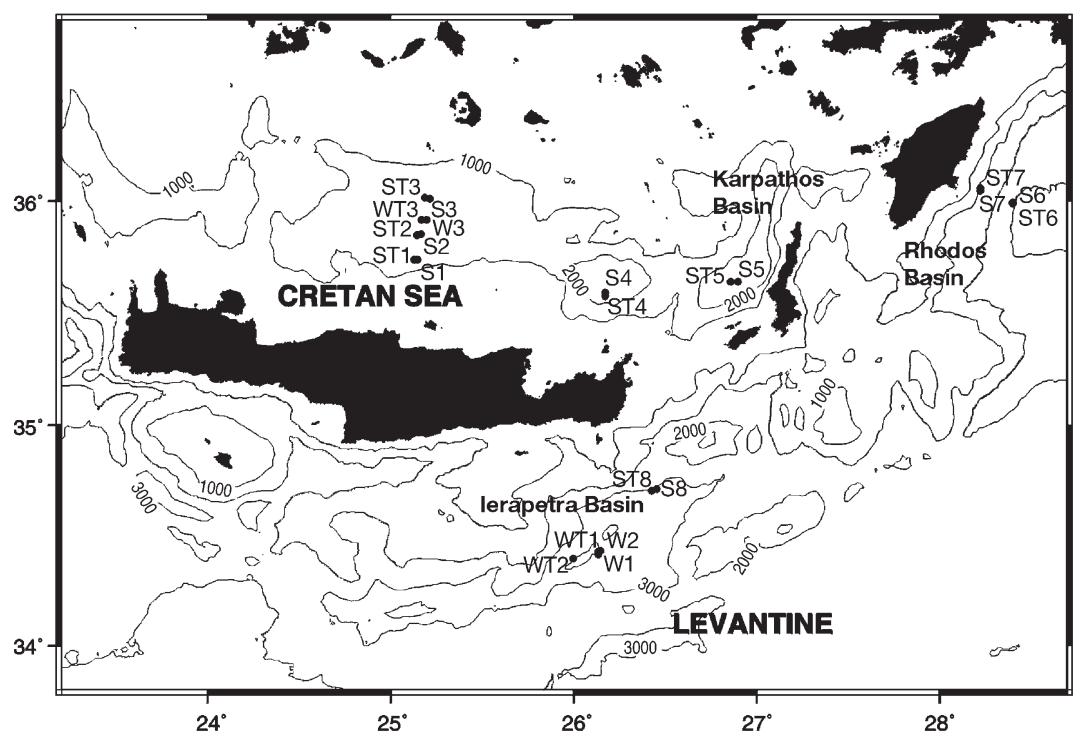

Fig. 1. Study area, showing positions of paired camera and trap deployments. All January stations have prefix W, June stations prefix S and trap deployments prefix T baits were compared between stations for indications of trends in relative abundance.

\section{MATERIALS AND METHODS}

A total of 11 stations were sampled in 1998, 3 in January during a cruise aboard RV 'Meteor', and a further 8 in June aboard RV 'Philia'. Fig. 1 indicates the positions of these stations and Table 1 gives details of each deployment depth and duration. In the Cretan Sea, deployments were made from $1500 \mathrm{~m}$ down to the maximum depth of $2490 \mathrm{~m}$ (in the Karpathos Basin). In the Rhodos Basin, 2 stations were sampled; one on the slope, the other at its base, between 3850 and $4000 \mathrm{~m}$. Finally, 3 sets of deployments were made in the Ierapetra Basin between 3000 and $4264 \mathrm{~m}$. At each station, paired deployments of the baited trap and time-lapse camera were made 1 nautical mile apart. This provided the opportunity of verifying identification of photographed species with trap samples, whilst minimising the interference between the 2 food sources.

System components and deployment methods. The AUDOS (Aberdeen University Deep Ocean Submersible) vehicle used in this study comprised an aluminium frame supporting a vertically orientated time-lapse camera (Umel) with twin flashlights, battery supply (DSPL, Deep Sea Power and Light) and a dual acoustic release system (Mors). Underwater, the frame was suspended between a mooring line providing positive buoyancy and a $2 \mathrm{~m}$ length of wire linked to a $120 \mathrm{~kg}$ ballast clump. This ballast, onto which a reference scale and bait (10 to $20 \mathrm{~kg}$ tuna pieces) were attached, rested on the seabed in view of the camera above. Photographs were taken at pre-set intervals of a $2.5 \mathrm{~m}$ area of the seabed. Ektachrome 200 ASA colour positive film was used, with a possible maximum of 800 frames. The time interval between photographs was set according to the deployment duration (Table 1). At the end of each deployment, the acoustic release system jettisoned the wire attached to the ballast clump, allowing the frame to return to the surface for recovery. Further details of the design and operation of the AUDOS vehicle used in these experiments can be found elsewhere (Bagley \& Priede 1997, Priede \& Bagley 2000).

At each station, the baited fish trap was deployed for between 12 and $36 \mathrm{~h}$. This consisted of a rectangular metal frame $(1000 \times 800 \times 800 \mathrm{~mm})$ covered 
with a $20 \mathrm{~mm}$ wire mesh, with 2 conical-shaped openings on opposite sides, one situated $100 \mathrm{~mm}$ above the bottom with an exterior diameter of $300 \mathrm{~mm}$ and an interior diameter of $150 \mathrm{~mm}$, the other situated $300 \mathrm{~mm}$ above the bottom and with exterior diameter of $400 \mathrm{~mm}$ and an interior diameter of $250 \mathrm{~mm}$. The trap was deployed and retrieved as a free-fall lander using glass flotation (Benthos) and an acoustic release (Mors). For each deployment, approximately 3 to $4 \mathrm{~kg}$ of squid and $1 \mathrm{~kg}$ of mackerel were used as bait.

Analysis of time-lapse photographs. Following processing, film was viewed on a microfilm viewer. Identification of species observed was made using relevant literature descriptions (e.g. Whitehead et al. 1984, Bellan-Santini et al. 1982a,b) and comparison with trap-caught specimens. Confidence in the identification of those species regularly observed in photographs and caught in the trap was high. However the identity of species rarely seen and not trapped remains tentative, but has been included for completeness. For every camera deployment, the number of each species observed in each frame was plotted over the duration of the experiment. The time of first arrival at the bait $\left(t_{1 \mathrm{st}}\right)$ and maximum number observed in any single frame ( Max $\left._{\text {species }}\right)$ were then compared between region and depth.

The high numbers of certain fish species attracted allowed analysis of length frequency distributions based on total body length measurements (tip of snout to tail) from the photographs. Only those individuals in full view and close to the reference scale were chosen, with a minimum interval of 20 min between measurements to reduce the probability of the same individual being repeatedly sampled.

\section{RESULTS}

A total of 18 putative species were trapped and/or photographed in this study, and are listed in Table 2 (photographic record) and Table 3 (trapped specimens). Decapod crustaceans were the only invertebrate fauna attracted: the caridian shrimp Acanthephyra eximia; 2 brachyuran crabs, Geryon longipes and Chaceon mediterraneus; a mysid; a leptostracan; and a variety of amphipods. The numbers trapped are given in Table 3, although washout of the smaller species is certain to have reduced these values. In the photographs, 4 shark species and 4 teleost fishes were identified, but not all of these were trapped. As a result, the identification of certain fishes remains speculative. Of the elasmobranchs photographed, Etmopterus spinax and Galeus melastomus were trapped and photographed, whereas Hexanchus griseus was too large to be trapped, but was easily identifiable in photographs. A
Table 1. Details of baited camera and trap deployments in the eastern Mediterranean. Stations from 'Meteor' Cruise 40/3, (28 December 1997 to 18 January 1998) have prefix W to denote winter; stations from 'Philia' Cruise (2 to 18 June 1998) have prefix $\mathrm{S}$ to denote summer; all trap deployments have prefix $\mathrm{T}$. Region, depth and duration of each deployment are given, and interval between photographs for camera deployments

\begin{tabular}{|c|c|c|c|c|}
\hline $\begin{array}{l}\text { Cruise } \\
\text { Region }\end{array}$ & $\begin{array}{l}\text { Stn } \\
\text { no. }\end{array}$ & $\begin{array}{l}\text { Depth } \\
\text { (m) }\end{array}$ & $\begin{array}{c}\text { Duration } \\
\text { (h) }\end{array}$ & $\begin{array}{c}\text { Interval } \\
\text { (min) }\end{array}$ \\
\hline \multicolumn{5}{|l|}{ Meteor 40/3 } \\
\hline \multirow[t]{2}{*}{ Ierapetra Basin } & W1 & 4264 & 115 & 10 \\
\hline & WT1 & 4262 & 20 & \\
\hline \multirow[t]{2}{*}{ Ierapetra Basin } & W2 & 4172 & 67 & 5 \\
\hline & WT2 & 4064 & 18 & \\
\hline \multirow[t]{2}{*}{ Cretan Sea } & W3 & 1873 & 92 & 5 \\
\hline & WT3 & 1832 & 25 & \\
\hline \multicolumn{5}{|l|}{ Philia } \\
\hline \multirow[t]{2}{*}{ Cretan Sea } & $\mathrm{S} 1$ & 1503 & 22 & 2 \\
\hline & ST1 & 1511 & 22 & \\
\hline \multirow[t]{2}{*}{ Cretan Sea } & $\mathrm{S} 2$ & 1822 & 48 & 5 \\
\hline & ST2 & 1831 & 18 & \\
\hline \multirow[t]{2}{*}{ Cretan Sea } & S3 & 1750 & 24 & 2 \\
\hline & ST3 & 1750 & 12 & \\
\hline \multirow[t]{2}{*}{ E. Cretan Sea } & $\mathrm{S} 4$ & 2220 & 23 & 2 \\
\hline & ST4 & 2230 & 12 & \\
\hline \multirow[t]{2}{*}{ Karpathos Basin } & S5 & 2490 & 24 & 2 \\
\hline & ST5 & 2485 & 12 & \\
\hline \multirow[t]{2}{*}{ Rhodos Basin } & $\mathrm{S} 6$ & 3850 & 24 & 2 \\
\hline & ST6 & 4067 & 36 & \\
\hline \multirow[t]{2}{*}{ Rhodos Basin } & S7 & 2307 & 22 & 2 \\
\hline & ST7 & 2270 & 12 & \\
\hline \multirow[t]{2}{*}{ Ierapetra Basin } & S8 & 3080 & 24 & 2 \\
\hline & ST8 & 3028 & 12 & \\
\hline
\end{tabular}

fourth species of intermediate length (estimated at between 0.5 and $1 \mathrm{~m}$ ) was observed at $1800 \mathrm{~m}$ in the Cretan Sea and $2307 \mathrm{~m}$ in the Rhodos Basin. This was believed to be either Centrophorus granulosus or Centroscymnus coelolepis. A species of Nettastomatidae (Anguilliformes) was observed at 1503 m. Nettastoma melanura Rafinesque, 1810 has been caught further east in the Levant basin at $1400 \mathrm{~m}$ depth (Galil \& Goren 1994) and in the western Mediterranean down to $1000 \mathrm{~m}$ (Stefanesu et al. 1992a) and was most likely to be the species photographed in this study.

\section{Regional and seasonal variation}

Due to the constraints of the sampling regime, rigorous regional and seasonal comparisons were not possible. The distribution of species numbers by region is illustrated in Fig. 2. All 18 species recorded were found in the Cretan Sea, 13 of these were also found in the Rhodos Basin and 4 species were common to all 3 regions. The 5 species exclusive to the 
Table 2. Results of the 11 baited camera deployments in the eastern Mediterranean. For the species present at each station, the maximum number observed in any 1 frame during the first $24 \mathrm{~h}$ of the deployment is given in bold, along with the time (min, in parentheses) of first arrival at the food-fall. Prefixes as in Table 1

\begin{tabular}{|c|c|c|c|c|c|c|c|c|c|c|c|}
\hline \multirow{4}{*}{ Species } & \multicolumn{11}{|c|}{ - Camera Stn no. and depth $(\mathrm{m})$} \\
\hline & \multirow{3}{*}{$\begin{array}{c}\text { S1 } \\
1503\end{array}$} & \multirow{3}{*}{$\begin{array}{c}\text { S3 } \\
1750\end{array}$} & \multicolumn{4}{|c|}{ - Cretan Sea } & \multicolumn{2}{|c|}{ Rhodos Basin } & \multicolumn{3}{|c|}{ Ierapetra Basin } \\
\hline & & & S2 & W3 & $\mathrm{S} 4$ & S5 & S7 & S6 & S8 & W2 & W1 \\
\hline & & & 1822 & 1873 & 2220 & 2490 & 2307 & 3850 & 3080 & 4172 & 4264 \\
\hline \multicolumn{12}{|l|}{ Crustacea: Decapoda } \\
\hline \multirow[t]{2}{*}{ Acanthephyra eximia Smith, 1886} & 31 & 30 & 191 & 85 & 44 & 18 & 130 & 20 & 13 & 24 & 48 \\
\hline & (6) & (10) & $(<5)$ & (10) & (6) & (10) & $(4)$ & (14) & (6) & $(<5)$ & (10) \\
\hline \multirow[t]{2}{*}{ Geryon longipes Milne Edwards, 1882} & 16 & $\mathbf{4}$ & 4 & 7 & & & & & & & \\
\hline & $(4)$ & $(156)$ & $(210)$ & $(25)$ & & & & & & & \\
\hline $\begin{array}{l}\text { Chaceon mediterraneus Manning, } \\
\text { Holthuis, } 1989\end{array}$ & & & & & $\begin{array}{c}3 \\
(64)\end{array}$ & $\begin{array}{c}13 \\
(75)\end{array}$ & $\begin{array}{c}9 \\
(44)\end{array}$ & $\begin{array}{c}3 \\
(720)\end{array}$ & $\begin{array}{c}14 \\
(252)\end{array}$ & & \\
\hline \multicolumn{12}{|l|}{ Elasmobranchii } \\
\hline Etmopterus spinax (Linnaeus, 1758) & 5 & 5 & 9 & 6 & 8 & 4 & 4 & & & & \\
\hline (Squalidae) & (10) & (34) & (25) & $(30)$ & (18) & (30) & $(54)$ & & & & \\
\hline Galeus melastomus Rafinesque, 1810 & 2 & 1 & 1 & 1 & & & & & & & \\
\hline (Scyliorhinidae) & $(22)$ & (90) & $(276)$ & $(150)$ & & & & & & & \\
\hline Hexanchus griseus (Bonnaterre, 1788) & 1 & 1 & 2 & 1 & 2 & & 1 & & & & \\
\hline (Hexanchidae) & $(286)$ & $(260)$ & $(285)$ & $(285)$ & $(540)$ & & $(250)$ & & & & \\
\hline $\begin{array}{l}\text { Centrophorus/Centroscymnus sp. } \\
\text { (Squalidae) }\end{array}$ & & & $\begin{array}{c}1 \\
(720)\end{array}$ & & & & $\begin{array}{c}1 \\
(720)\end{array}$ & & & & \\
\hline \multicolumn{12}{|l|}{ Teleostei } \\
\hline Nemattostomatidae & $\begin{array}{c}1 \\
(166)\end{array}$ & & & & & & & & & & \\
\hline $\begin{array}{l}\text { Lepidion lepidion (Risso, 1810), L. guntheri } \\
\text { (Moridae) }\end{array}$ & & $\begin{array}{c}1 \\
(256)\end{array}$ & $\begin{array}{c}2 \\
(36)\end{array}$ & $\begin{array}{c}2 \\
(15)\end{array}$ & $\begin{array}{c}2 \\
(60)\end{array}$ & & $\begin{array}{c}2 \\
(36)\end{array}$ & & & & \\
\hline $\begin{array}{l}\text { Chalinura mediterranea Giglioli, } 1893 \\
\text { (Macrouridae) }\end{array}$ & & & $\begin{array}{c}2 \\
(380)\end{array}$ & & $\begin{array}{c}1 \\
(340)\end{array}$ & $\begin{array}{c}6 \\
(80)\end{array}$ & & $\begin{array}{c}\mathbf{8} \\
(22)\end{array}$ & $\begin{array}{c}4 \\
(106)\end{array}$ & $\begin{array}{c}26 \\
(45)\end{array}$ & $\begin{array}{c}23 \\
(60)\end{array}$ \\
\hline
\end{tabular}

Cretan Sea were only found at the shallower depths, between 1500 and $1800 \mathrm{~m}$, and were not sampled in the other regions. Deployments between 2000 and $2500 \mathrm{~m}$ were made in both the Cretan Sea and the Rhodos Basin and there was little difference in the species attracted. Greater numbers of Acanthephyra eximia and Chaceon mediterraneus were recorded on the Rhodos slope, and the first arrival time for Hexa-

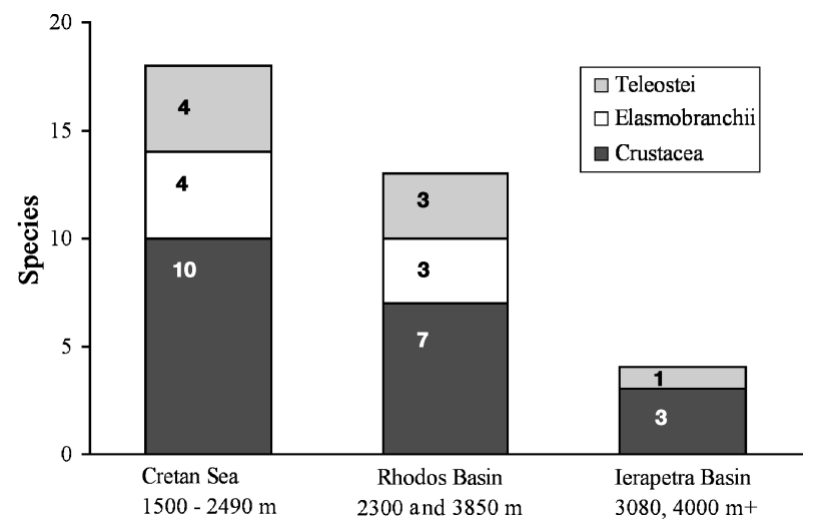

Fig. 2. Number of species observed by camera or trapped in the 3 regions sampled. Numbers of crustaceans, elasmobranchs and teleosts in each region are indicated inside bars nchus griseus was less than half its arrival time in the Cretan Sea. Comparative camera and trap stations were also sampled at abyssal depths in the Rhodos and Ierapetra Basins. A. eximia, Chalinura mediterranea and $C$. mediterraneus were present in both regions. Comparative winter and summer deployments were made at $1800 \mathrm{~m}$ in the Cretan Sea only. The scavenger assemblage attracted was similar, apart from the absence of $C$. mediterranea and the unknown shark species.

\section{Bathymetric distribution range of bait-attracted species}

Due to the general similarities in bait-attending fauna between regions, it was considered feasible to compare all stations together for the purposes of analysing bathymetric distributions of the species observed. These were inferred from presence and absence in traps and on camera films, and are shown in Fig. 3. Acanthephyra eximia was photographed at baits over the entire depth range sampled, from 1500 to $4264 \mathrm{~m}$. Other crustaceans had more limited ranges. The crab Geryon longipes was trapped between 1500 
Table 3. Results of the 11 baited trap deployments in the eastern Mediterranean. Prefixes as in Table 1; x indicates species present but numbers not available

\begin{tabular}{|c|c|c|c|c|c|c|c|c|c|c|c|}
\hline \multirow{4}{*}{ Species } & \multicolumn{11}{|c|}{ Trap Stn no. and depth $(\mathrm{m})$} \\
\hline & \multirow{3}{*}{$\begin{array}{c} \\
\text { ST1 } \\
1511\end{array}$} & \multirow{3}{*}{$\begin{array}{c}\text { ST3 } \\
1750\end{array}$} & \multicolumn{2}{|c|}{ - Cretan Sea- } & \multicolumn{2}{|c|}{$2+\frac{1}{2}$} & \multicolumn{2}{|c|}{ Rhodos Basin } & \multicolumn{3}{|c|}{ Ierapetra Basin } \\
\hline & & & ST2 & WT3 & ST4 & ST5 & ST7 & ST6 & ST8 & WT2 & WT1 \\
\hline & & & 1831 & 1832 & 2230 & 2485 & 2270 & 4067 & 3028 & 4064 & 4262 \\
\hline \multicolumn{12}{|l|}{ Crustacea: Decapoda } \\
\hline Acanthephyra eximia Smith, 1886 & & $\mathrm{x}$ & 10 & $\mathrm{x}$ & $\mathrm{x}$ & $\mathrm{x}$ & $\mathrm{x}$ & & $\mathrm{x}$ & $\mathrm{x}$ & $\mathrm{x}$ \\
\hline Geryon longipes Milne Edwards, 1882 & 32 & 3 & 5 & & & & & & & & \\
\hline $\begin{array}{l}\text { Chaceon mediterraneus Manning \& } \\
\text { Holthuis, } 1989\end{array}$ & & & & & 25 & 19 & 53 & & 8 & & \\
\hline Scopelocheirus hopei (Costa, 1851) & & 30 & 105 & 19 & 35 & 2 & 1 & & & & \\
\hline $\begin{array}{l}\text { S. polymedus } \\
\text { Bellan-Santini, } 1985\end{array}$ & 1 & & & & & & & & & & \\
\hline Epimeria cf. cornigera (Fabricius, 1779) & & & & & 19 & & 6 & & 23 & & \\
\hline Orchomene grimaldii Chevreux, 1890 & & & 1 & 3 & 3 & & 2 & & & & \\
\hline Orchomenella nana (Kröyer, 1846) & 8 & & & & & & & & & & \\
\hline Nebaliacea & & 1 & & 14 & 16 & 1 & 5 & & & & \\
\hline Mysidacea & & 1 & & & 3 & 4 & 11 & & & & \\
\hline \multicolumn{12}{|l|}{ Elasmobranchii } \\
\hline $\begin{array}{l}\text { Etmopterus spinax (Linnaeus, 1758) } \\
\text { Galeus melastomus Rafinesque, } 1810\end{array}$ & & & & 1 & 1 & & & & & & \\
\hline \multicolumn{12}{|l|}{ Teleostei } \\
\hline Lepidion lepidion (Risso, 1810) & 1 & 1 & & & & & 2 & & & & \\
\hline Chalinura mediterranea Giglioli, 1893 & & & & & & & & 1 & & 12 & 13 \\
\hline
\end{tabular}

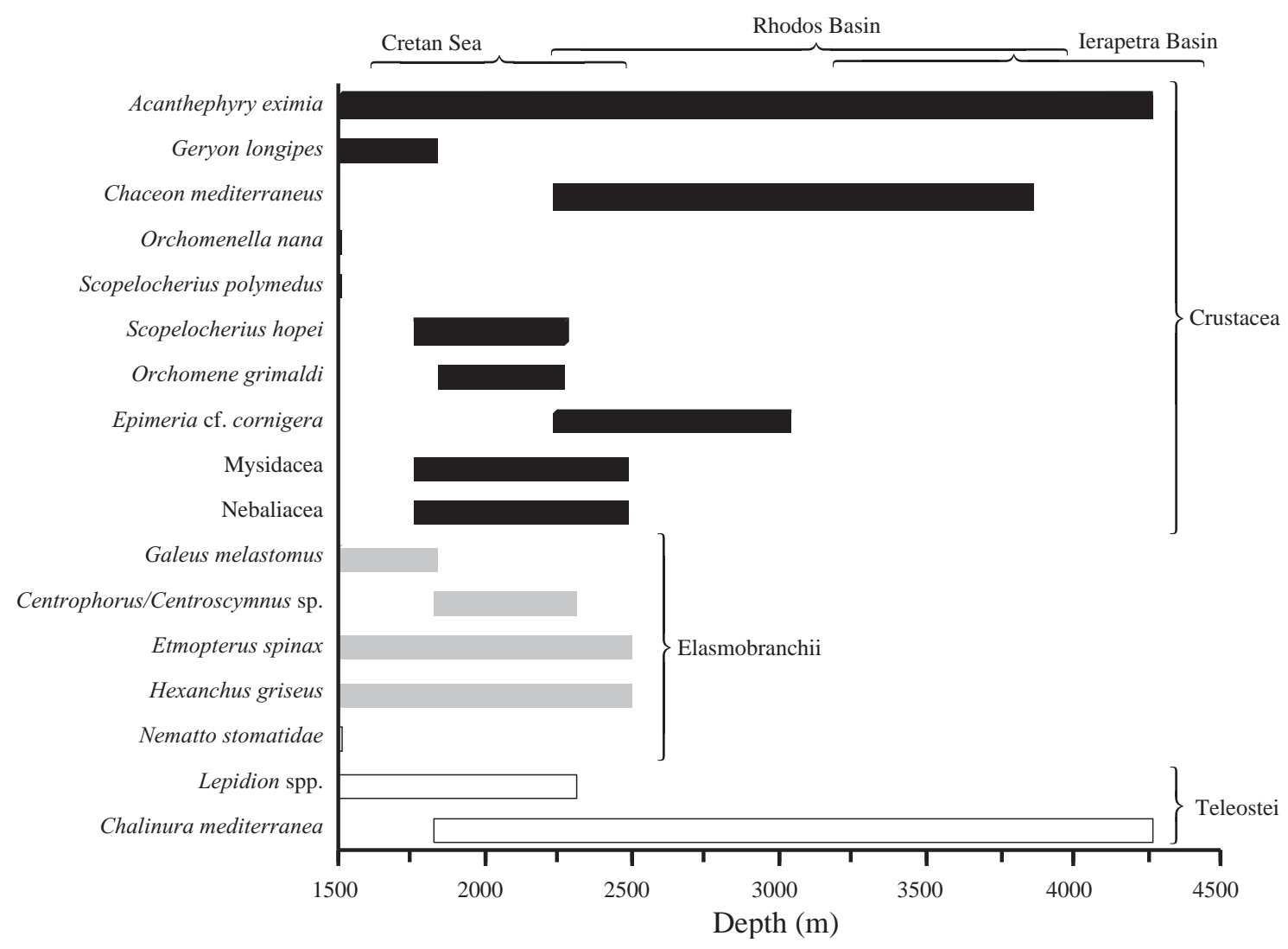

Fig. 3. Bathymetric distributions below $1500 \mathrm{~m}$ of crustaceans, elasmobranchs and teleosts inferred from their occurrence at baited camera and/or trap deployments. Depth ranges sampled in the 3 regions are also indicated 


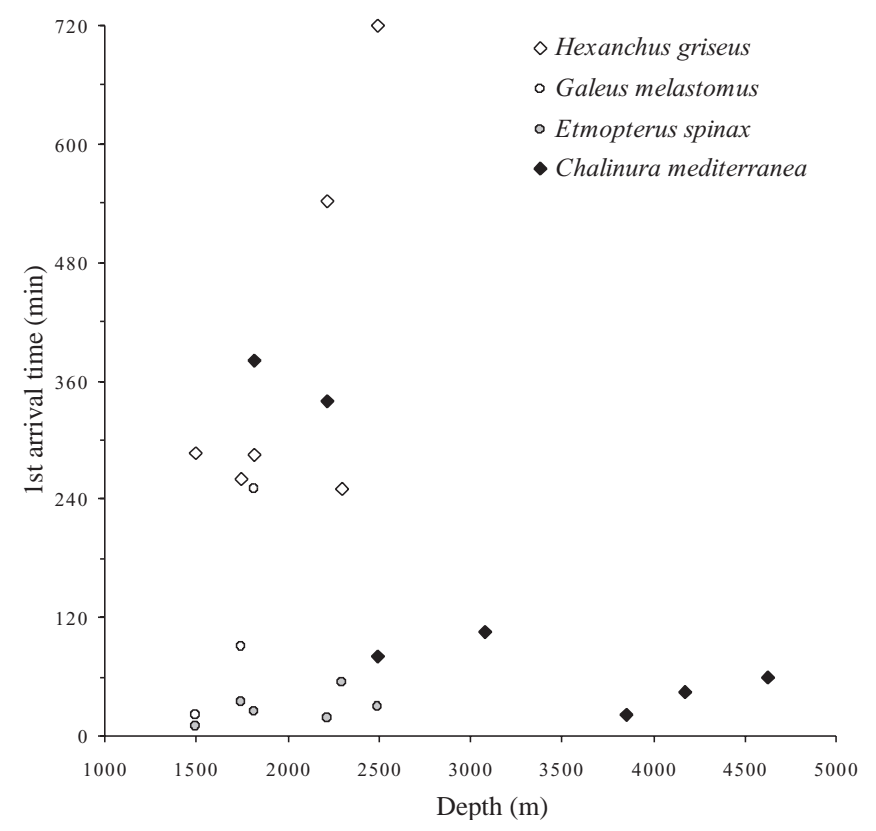

Fig. 4. Variation in first arrival time at the bait with station depth for 3 elasmo-branch species and the macrourid Chalinura mediterranea

and $1830 \mathrm{~m}$. A second geryonid, Chaceon mediterraneus, was only found deeper, from $2230 \mathrm{~m}$ down to $3028 \mathrm{~m}$. This was also the assumed identity of crabs observed on the films from the concurrent camera deployments. Although not trapped at Stn 6 (4067 m), this species was observed at the paired camera station $(3850 \mathrm{~m})$. A succession of amphipod species were trapped between 1500 and $3028 \mathrm{~m}$ (shown in Fig. 3), 1 of which, Epimeria cf. cornigera, was found in all 3 regions.

Sharks dominated the fish assemblage between 1500 and $2500 \mathrm{~m}$. The catshark Galeus melastomus was observed from 1500 to $1830 \mathrm{~m}$ only. The sixgill shark Hexanchus griseus was by far the largest scavenger. Both H. griseus and the small lantern shark Etmopterus spinax were attracted at every station between 1500 and $2490 \mathrm{~m}$. No sharks were observed at greater depths.

Between 1500 and 3080 m, 4 species of teleosts were identified, although the numbers attracted were low. The 1 species of Nemattostomatidae was photographed at $1500 \mathrm{~m}$ only. A morid, Lepidion lepidion, was photographed and trapped at the 2 shallowest stations (1503 and $1750 \mathrm{~m}$ ). Between 1800 and $2300 \mathrm{~m}$, L. lepidion and a second species were photographed but not trapped. This second species was thought to be L. guentheri. The only fish attracted to bait below $2500 \mathrm{~m}$ was the macrourid Chalinura mediterranea, which had the widest depth range of all vertebrates (from 1822 to $4264 \mathrm{~m}$ ).

\section{Relative abundance inferred from first arrival times}

The time of first arrival ( $\left.t_{1 \text { st }}\right)$ for 3 elasmobranch species and Chalinura mediterranea are plotted against depth in Fig. 4. For Galeus melastomus and H. griseus there was a clear trend of increase in $t_{1 \mathrm{st}}$ as depth increased. From this, a decline in relative abundance was inferred for these species with increasing depth. In contrast, a decrease in $t_{1 \text { st }}$ (Fig. 4) and corresponding increase in maximum numbers (Table 2) of $C$. mediterranea was observed with increasing depth, suggesting a higher abundance at greater depths. The maximum numbers given in Table 2 are for the first $24 \mathrm{~h}$ of these 2 deployments in order to be comparable with the other results. However, fish numbers continued to increase at the deepest station, reaching 49 individuals after $115 \mathrm{~h}$.

\section{Bathymetric trends in size}

Length estimates of photographed fishes were made where possible. For Etmopterus spinax and Chalinura mediterranea, sufficient data were collected to allow frequency distributions to be plotted at different depths (Fig. 5). No significant change in size was detected for either species over their observed depth range. For $C$. mediterranea, the overall mean length of $198 \mathrm{~mm}(\mathrm{n}=328, \mathrm{SD}=30 \mathrm{~mm}$, range $=120$ to $296 \mathrm{~mm})$ compared favourably with the mean length of $191 \mathrm{~mm}$ for trapped specimens $(\mathrm{n}=25, \mathrm{SD}=27 \mathrm{~mm}$, range $=$ 155 to $260 \mathrm{~mm})$. For E. spinax, the mean length was $332 \mathrm{~mm}$ ( $\mathrm{n}=125, \mathrm{SD}=40 \mathrm{~mm}$, range $=247$ to $450 \mathrm{~mm})$. A limited number of length estimates were obtained for Galeus melastomus: mean length was $439 \mathrm{~mm}$ ( $\mathrm{n}=$ $11, \mathrm{SD}=46 \mathrm{~mm}$, range $=370$ to $500 \mathrm{~mm}$ ). Estimated total lengths for Hexanchus griseus ranged from 1.15 to at least $3.0 \mathrm{~m}$. As a consequence of the change in species dominance with increasing depth, the average length of fishes at stations $2500 \mathrm{~m}$ and shallower was greater than that of fishes observed at the deeper stations.

\section{Bait consumption and variation in numbers over time}

The pattern of variation in numbers of individuals attracted to the bait over the course of each deployment differed between species and according to the scavenging activity of Hexanchus griseus; some examples are given in Fig. 6. Acanthephyra eximia was attracted to every deployment within $10 \mathrm{~min}$. Typically, numbers reached a peak within the first 1 to $2 \mathrm{~h}$. At shallow deployments, where the bait was attacked by $H$. griseus, shrimp numbers fluctuated until the bait 
was consumed. At deeper stations, where the bait was not fully consumed or remained intact, numbers declined and remained low for the rest of the deployment (Fig. 6c). A similar pattern was observed for the smaller shark Etmopterus spinax: peak numbers of up to 5 individuals were reached in the first few hours prior to the arrival of the sixgill sharks, declining to intermittent sightings thereafter. In contrast, the arrival rates of the 2 crab species were much slower, with numbers increasing steadily over the course of the deployment (Fig. 6b) unless the bait was completely consumed (Fig. 6a). The macrourid Chalinura mediterranea was only observed in any numbers at the deeper stations (2490 $\mathrm{m}$ and greater) and showed a similar pattern of steady build-up of individuals over the course of the deployment (Fig. 6b,c).

At all stations where sixgill sharks were attracted, the bait was consumed, although not always completely within the $24 \mathrm{~h}$ period. Their attacks dispersed chunks of the bait and stirred up the sediment, often attracting increased number of smaller scavengers once they had departed. At $3080 \mathrm{~m}$, swarms of amphipods were visible on the surface of the bait, although the exact amount consumed was unknown since retrieval was not possible. At the 3 deeper stations, where only Acanthephyra eximia and Chalinura mediterranea were attracted, the bait appeared mostly untouched, with no indication of skin removal or reduction in size, despite the high numbers of fish and shrimp present.

\section{DISCUSSION}

The benthic and benthopelagic megafauna attracted to baited camera and trap deployments in this study consisted of decapod crustaceans and elasmobranch and teleost fishes. These taxa also dominate trawl catches in this and other regions in the Mediterranean (Kallianiotis et al. 2000, Cartes et al. 2001). Greater species diversity is found by trawling, although the dominant species in terms of biomass and numbers are similar for both methods of sampling; Stefanescu et al. (1992a) recorded 16 species of demersal fishes in the western Mediterranean between 1501 and 2250 m com- pared with 8 species recorded in this study. However, they found that $85 \%$ of the specimens captured came from 3 families: Chlorophthalmidae (Bathypterois mediterraneus), Moridae (Lepidion lepidion and $L$. guentheri) and Macrouridae (including Chalinura mediterranea). Hexanchus griseus dominated in terms of biomass and Macrouridae, Squalidae and Moridae were found to be the most important families in terms of species.

Camera and trap deployments encompassed 3 different regions and differing depth ranges. However, where station depths were similar the fauna attracted was broadly similar. The comparison between the Cretan Sea and Rhodos Basin suggested higher abundance of benthic and benthopelagic fauna in the latter. This was thought to be a consequence of higher productivity in this region due to a localised upwelling (Krom et al. 1992).
(1)
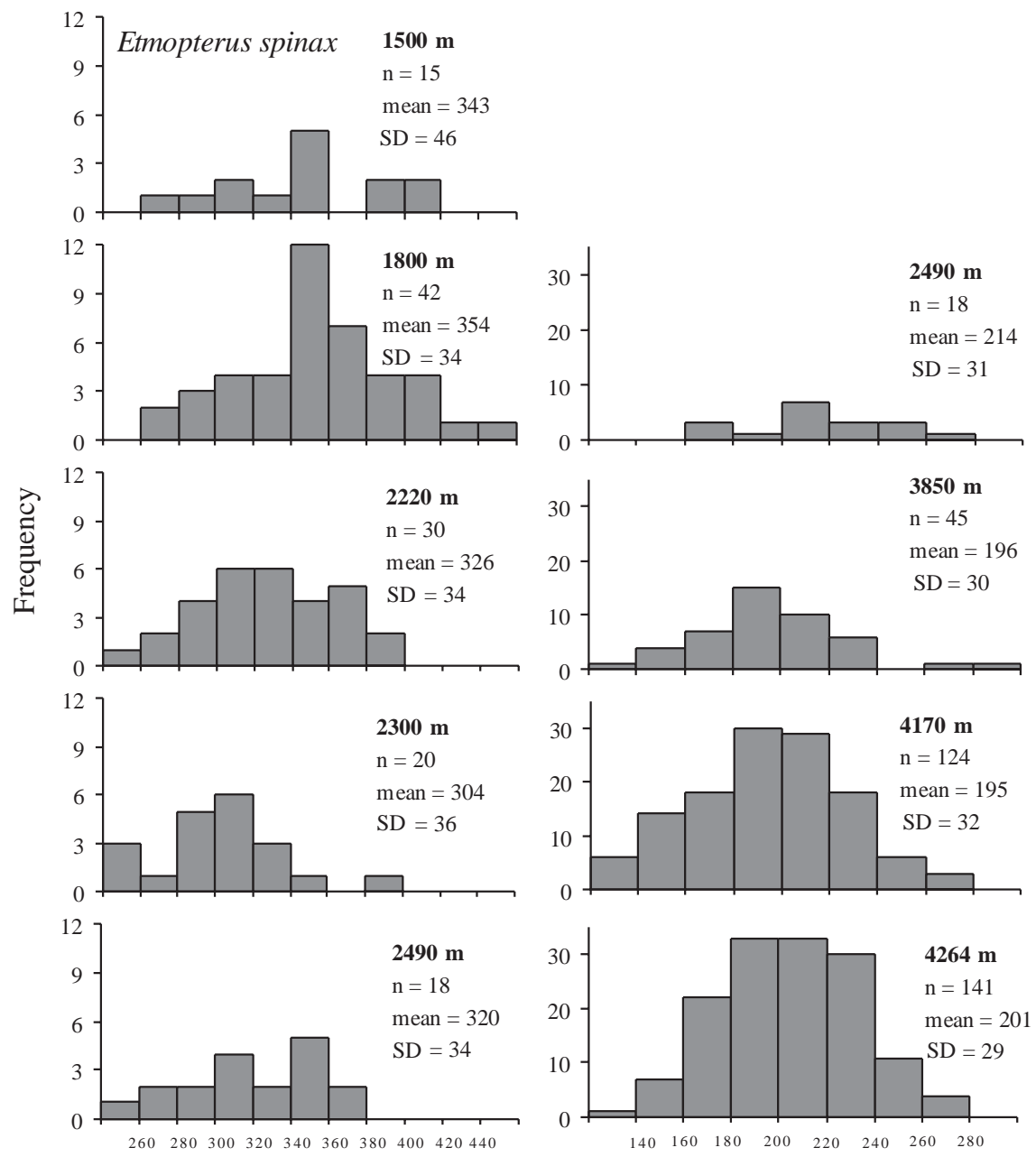

Total length (mm)

Fig. 5. Etmopterus spinax and Chalinura mediterranea. Total length-frequency distributions at stations of different depths, giving sample size, mean length and standard deviation for each depth 

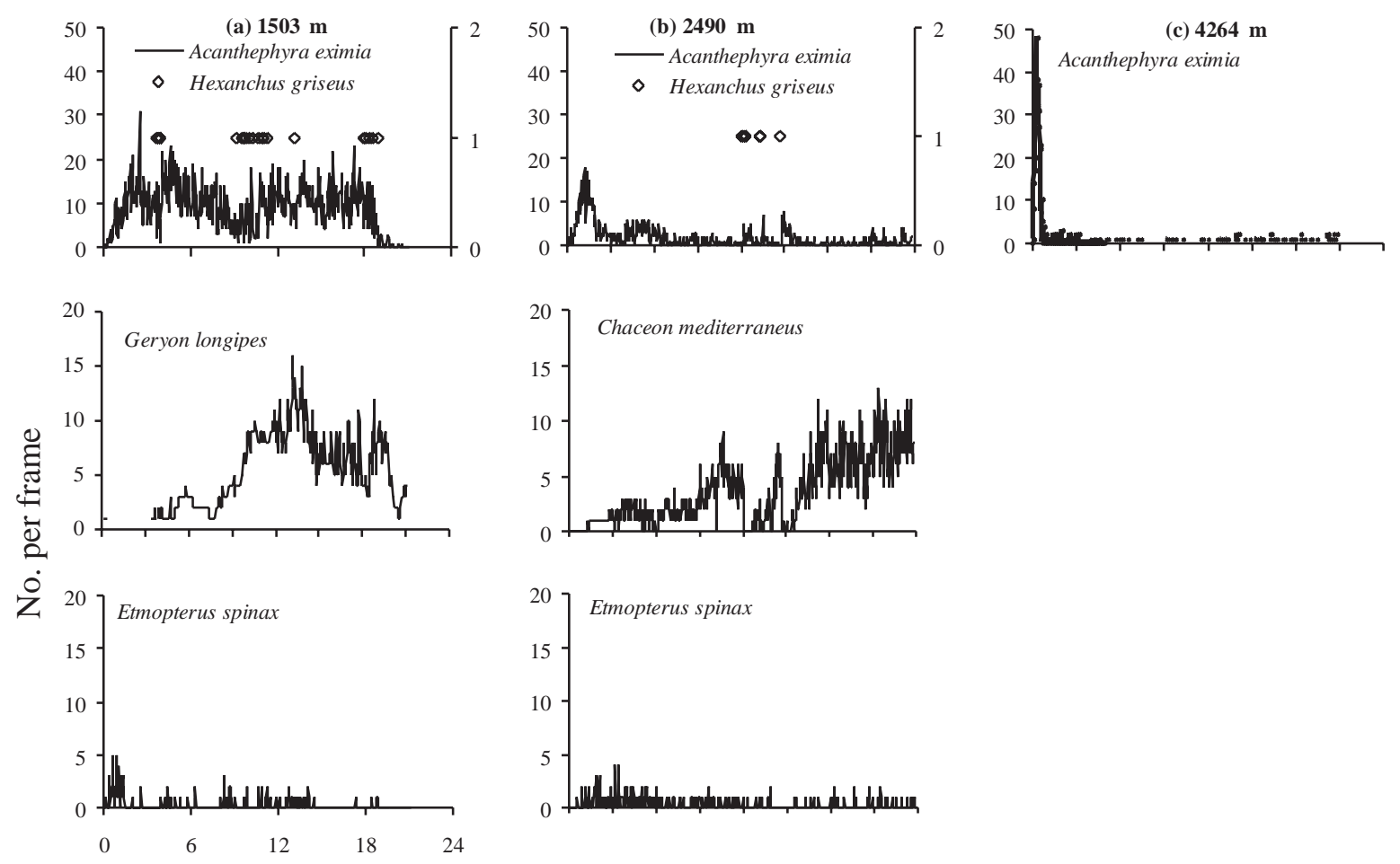

Fig. 6. Variation in numbers per frame of the most common species observed during 3 of the 11 camera deployments. (a) Stn S1, 1503 m Cretan Sea; (b) Stn S5, 2490 m, Karpathos Basin; (c) Stn W1, $4264 \mathrm{~m}$, Ierapetra Basin.

$(\diamond)$ Single sightings of Hexanchus griseus (scales on right-hand side)
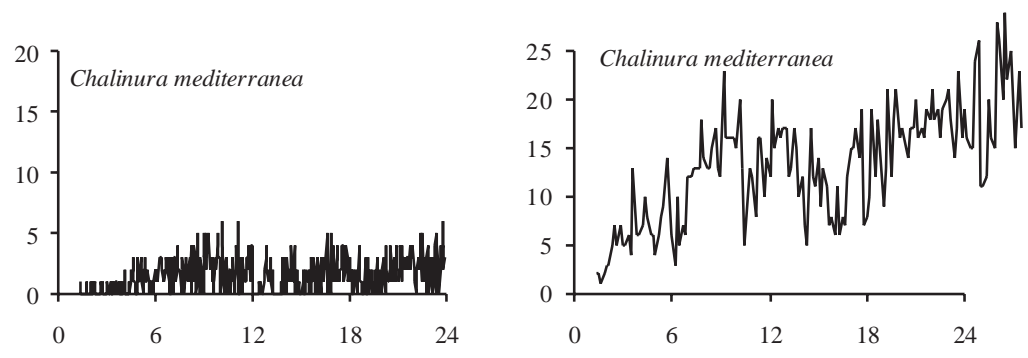

Time after arrival of bait on sea floor (h)

\section{Bathymetric distribution}

Much of the fauna of the Mediterranean Sea is believed to have originated from the Atlantic Ocean (Fredj \& Laubier 1985, Bouchet \& Taviani 1992). However, many of the species characteristic of baited camera experiments in the abyssal NE Atlantic were not observed here in the Mediterranean, e.g. Coryphaenoides armatus, zoarcids, liparids, ophidiids, deep-water eels and lysianassid amphipods such as Eurythenes gryllus and Paralicella sp. (Armstrong et al. 1992, Thurston et al. 1995, Jones et al. 1998, Henriques et al. 2002). Their absence is generally thought to be due to a combination of dispersal barriers including the shallow sill at Gibraltar, deep outflowing current, and the high temperatures at depth $\left(13\right.$ to $14^{\circ} \mathrm{C}$ compared to 2 to $4^{\circ} \mathrm{C}$ in the Atlantic). As a consequence, some bathyal species have apparently extended their depth range into the abyssal environment. The geryonid crab Chaceon mediterraneus was previously noted only in the western Mediterranean from 1990 to $2830 \mathrm{~m}$ (Cartes 1993a), and has been trapped in the present study for the first time in the eastern Mediterranean (Koukouras et al. 2000). The specimens collected from $3028 \mathrm{~m}$ and observations at $3850 \mathrm{~m}$ extend the known depth range of this species by $1000 \mathrm{~m}$. Geryonid crabs occur widely in the world's oceans, but are rare below $2000 \mathrm{~m}$ (Attrill et al. 1990). Temperature is believed to be the limiting factor to their distribution (Gage \& Tyler 1991), and this may explain their presence here in the eastern Mediterranean, where the water is unusually warm at abyssal depths. The amphipods Epimeria cornigera and Orchomenella nana have been recorded previously in the Mediterranean down to 430 and $460 \mathrm{~m}$ respectively (Bellan-Santini et al. 1982b). In this study they were trapped as deep as 3028 and $2270 \mathrm{~m}$ respectively. The elasmobranch Galeus melastomus was rarely found in trawl catches below $1400 \mathrm{~m}$ in the western Mediterranean (Carrassón et al. 1992), but in this study it was regularly observed and also trapped down to $1830 \mathrm{~m}$. Both Etmopterus spinax and Hexanchus griseus were 
observed at $2490 \mathrm{~m}$, at the known limit of both their depth distributions. The fourth shark species observed at 1800 and $2300 \mathrm{~m}$ could not be identified with certainty. Centrophorus granulosus has been caught in this region as deep as $1000 \mathrm{~m}$ (Kallianiotis et al. 2000) and further east at $1490 \mathrm{~m}$ (Gilat \& Gelman 1984), but is not thought to occur much deeper. Although not previously recorded in this region, Centroscymnus coelolepis was found as deep as $2251 \mathrm{~m}$ further west in the Catalan Sea (Carassón et al. 1992) and was thought to be the most likely identity of the shark observed in this study. Lepidion lepidion was observed from 1500 to 2490 m, in the Cretan Sea. Between 1822 and $2490 \mathrm{~m}$ a second, larger teleost, thought to be $L$. guentheri, was also photographed at the baits, but not trapped. This pattern of occurrence agrees with observations in the Catalan Sea where L. guentheri is rare but overlaps with L. lepidion over 1600 to 2239 m (Carrassón et al. 1997, Moranta et al. 1998). Below 4000 m, only Acanthephyra eximia and Chalinura mediterranea were attracted to bait. Both species have a bathyal distribution elsewhere: A. eximia from 200 to $2500 \mathrm{~m}$ in the Atlantic and Indo-Pacific (Crosnier \& Forest 1973); $C$. mediterranea from 1750 to $2250 \mathrm{~m}$ in the NE Atlantic (Mauchline \& Gordon 1984), and 1400 to $2500 \mathrm{~m}$ in the western Mediterranean (Stefanescu et al. 1993, Moranta et al. 1998). In the eastern Mediterranean, both species are widespread at 3000 to $4500 \mathrm{~m}$, as evidenced by this and previous studies (Christiansen 1989, Albertelli et al. 1992, Della Croce \& Albertelli 1995).

\section{Bathymetric trends in number of species, relative abundance and size}

There was a clear decline in number of species observed with increasing depth: 18 recorded at $1503 \mathrm{~m}$ compared with 2 at $4264 \mathrm{~m}$. Amongst the fishes attracted, elasmobranchs dominated between 1500 and $2500 \mathrm{~m}$, but below this depth the macrourid Chalinura mediterranea was the only fish present. The relationship between $t_{1 \mathrm{st}}$ and depth for a number of fishes and decapod species reflected this change. Although lack of information on current speed variation and swimming and walking speeds for each species prevented actual abundance estimates being calculated, the trends suggested a decline in relative abundance for elasmobranchs but an increase for the macrourid. The pattern of bathymetric change in bait-attending species observed in this study has similarities to observations made in the Bay of Biscay, NE Atlantic, where Centroscymnus coelolepis was replaced by the macrourid Coryphaenoides (Nematonurus) armatus as the dominant species with increasing depth (Desbruyérès et al. 1985).
Due to the stability of physical environmental factors such as temperature, it is believed that reduced food availability with increasing depth is the principal factor responsible for the decline in species diversity. This has been demonstrated for macrobenthos in the Cretan Sea (Tselepides \& Eleftheriou 1992, Tselepides et al. $2000 \mathrm{~b}$ ) and is likely to be the case for the megafauna as well. As a consequence of this decline in trophic resources and resulting change in species composition with increasing depth, a decline in fish size was apparent. This has been noted in the western Mediterranean for both fishes (Stefanescu et al. 1992b, 1993) and decapod crustaceans (Sardà \& Cartes 1993). Stefanescu $(1992 b, 1993)$ found a distinct fish assemblage above $1200 \mathrm{~m}$, consisting of large gadiiform fish species characterised by higher energy requirements, that were replaced at greater depths by smaller species such as Chalinura mediterranea with lower energy requirements.

Within-species depth-size trends have been a muchdebated topic, with some believed to be an artefact of sampling techniques (Haedrich \& Merrett 1990, Macpherson \& Duarte 1991, Merrett \& Haedrich 1997). Previous studies in the western Mediterranean have concluded that, in contrast to the adjacent Atlantic, the majority of demersal fish species between 1000 and $2250 \mathrm{~m}$, including many macrourids, do not show any clear depth-size trend (Stefanescu et al 1992b). In this study, no significant difference in the size distribution of Chalinura mediterranea was observed between 2490 and $4264 \mathrm{~m}$. A similar result was obtained for Etmopterus spinax, contradicting the bigger-deeper trend observed in the western basin (Carrassón et al. 1992).

\section{Bait consumption}

Although bait was visibly consumed at shallow stations, it is unlikely that necrophagy is an important feeding mode for any of the species observed. The most active scavenger of the bait was Hexanchus griseus, the diet of which has yet to be documented in the eastern Mediterranean. However, in the productive waters off South Africa, it is a eurytrophic predator feeding on cephalopods, crustaceans, teleosts and other elasmobranchs, with marine mammals forming an increasing part of the diet as the shark grows larger (Ebert 1994). The preferred prey of Galeus melastomus below $1000 \mathrm{~m}$ in the western Mediterranean were cephalopods, teleost fishes and decapods such as Geryon longipes (Carrasón et al. 1992). Scavenging was not thought to be important in its diet. Etmopterus spinax has a strong pelagic habit and preys mainly on cephalopods (Macpherson 1980). The diets of the teleost fish species observed have been studied in the 
western basins, and all have been found to be eurytrophic predators, with natantian decapods such as Acanthephyra eximia, A. pelagica, mysids, copepods and amphipods comprising important prey items (Carrassón \& Matallanas 1990, 2002, Carrasón et al. 1997). It is therefore feasible that many of the fishes may have been preying on the crustaceans attracted to the bait rather than on the bait itself. The success of $A$. eximia and Chalinuara mediterranea at depths where the other species were absent is thought to be due to a combination of their small size, mobility and opportunistic and euryphagic feeding strategy. A. eximia itself has been shown to have a varied diet including natantian decapods and hyperiid amphipods (Cartes \& Maynou 1998), but with an increasing trend towards scavenging and detritivory at greater depths (Cartes 1993b). This was certainly the first species to arrive at baits in almost every deployment, but numbers often declined once fishes began to arrive. This does not explain the lack of bait consumption at the deeper stations, but this may have been due to the inability of $A$. eximia to penetrate the intact skin on tuna carcasses. This phenomenon has been noted elsewhere with baited camera experiments using cetaceans (Jones et al. 1998) and mackerel (I. G. Priede pers. obs.).

This study has provided valuable new information on composition, distribution and depth ranges of natatory benthopelagic megafauna in the eastern Mediterranean. Such fauna can be difficult to catch with other sampling techniques. Whilst clearly a versatile technique for research vessels working in deep waters without the size or capability for deep-water trawling, the fauna which can be sampled is limited to sufficiently mobile opportunistic scavengers. It is possible that other species may have been observed if, for instance, the deployments had been made for longer periods with protected bait. In the NE Atlantic, long deployments with large bait attracted opportunistic scavenging echinoderms and crustaceans not observed at short $24 \mathrm{~h}$ deployments (Jones et al. 1998). It is also possible that some species may have been deterred by the presence of other, more aggressive scavengers, such as the larger sharks. Trawling samples a much broader range of species, although this method also has its limits and biases, and ideally a combination of these 2 techniques would allow a thorough survey of the deep fauna of this little-studied region.

Acknowledgements. This work was supported by NERC grant GR3/10162 and European Commission MAST 3 contract CT950010 to I.G.P., and a NERC studentship to E.G.J. The authors would like to thank the ship's company of the FS 'Meteor' (Cruise 40/3) and RV 'Philia', Bernd Christansen, Steve Addison and Thalia Polychronaki. Simon Greenstreet and 4 anonymous referees provided helpful comments on the manuscript.

\section{LITERATURE CITED}

Albertelli G, Arnaud PM, Della Croce N, Drago N, Eleftheriou A (1992) The deep Mediterranean macrofauna caught in traps and its trophic significance. C R Acad Sci Ser III 31: 139-144

Armstrong JD, Bagley PM, Priede IG (1992) Photographic and acoustic tracking observations of the behaviour of the grenadier Coryphaenoides (Nematonurus) armatus, the eel Synaphobranchus bathybius, and other abyssal demersal fish in the North Atlantic Ocean. Mar Biol 112: $535-544$

Attrill MJ, Hartnoll RG, Rice AL, Thurston MH (1990) A depth related distribution of the red crab Geryon trispinosus (Herbst) [= G. tridens Krøyer]: indications of vertical migrations. Prog Oceanogr 24:197-206

Bagley PM, Priede IG (1997) An autonomous free-fall acoustic tracking system for investigation of fish behaviour at abyssal depths. Aquat Living Resour 10:67-74

Bellan-Santini D, Diviacco G, Krapp-Schikel G, Myers A, Ruffo S (1982a) The Amphipoda of the Mediterranean. Part 2, Gammaridea (Haustorriidae to Lysianassidae). (Copia). Mém Inst Océanogr, Monaco, 13:813

Bellan-Santini D, Karaman G, Krapp-Schikel G, Ledoyer M, Ruffo S (1982b) The Amphipoda of the Mediterranean. Part 3, Gammaridea (Melphidippidae to Talitridae), Ingolfiellidea, Caprellidea. Mém Inst Océanogr, Monaco, 13:365-576

Bouchet P, Taviani M (1992) The Mediterranean deep-sea fauna: pseudopopulations of Atlantic species? Deep-Sea Res I 39:169-184

Carney RS, Haedrich RL, Rowe GT (1983) Zonation of fauna in the deep-sea. In: Rowe GT (ed) Deep-sea biology of the sea, Vol 8. Wiley-Interscience, New York, p 378-398

Carrassón M, Matallanas J (1990) Preliminary data about the feeding habits of some deep-sea Mediterranean fishes. J Fish Biol 36:461-463

Carrassón M, Matallanas J (2002) Diets of deep-sea macrourid fishes in the western Mediterranean. Mar Ecol Prog Ser 234:215-228

Carrassón M, Stefanescu C, Cartes JE (1992) Diets and bathymetric distributions of 2 bathyal sharks of the Catalan deep sea (western Mediterranean). Mar Ecol Prog Ser 82: 21-30

Carrassón M, Matallanas J, Casadevall M (1997) Feeding strategies of deep-water morids on the western Mediterranean slope. Deep-Sea Res 44:1685-1699

Cartes JE (1993a) Deep-sea decapod fauna of the western Mediterranean-bathymetric distribution and biogeographic aspects. Crustaceana 65:29-40

Cartes JE (1993b) Feeding habits of oplophorid shrimps in the deep western Mediterranean. J Mar Biol Assoc UK 73: 193-206

Cartes JE, Maynou F (1998) Food consumption by bathyal decapod crustacean assemblages in the western Mediterranean: predatory impact of megafauna and the food consumption - food supply balance in a deep-water food web. Mar Ecol Prog Ser 171:233-246

Cartes JE, Maynou F, Morales-Nin B, Massutí E, Moranta J (2001) Trophic structure of a bathyal benthopelagic boundary layer community south of the Balearic islands (southwestern Mediterranean). Mar Ecol Prog Ser 215:23-35

Christiansen B (1989) Acanthephyra sp. (Crustacea: Decapoda) in the eastern Mediterranean sea captured by baited traps. Senckenb Marit 20:187-193

Collins MA, Yau C, Nolan CP, Bagley PM, Priede IG (1999) behavioural observations on the scavenging fauna of the 
Patagonian slope. J Mar Biol Accoc UK 79:963-970

Crosnier A, Forest J (1973) Les crevettes profondes de l'Atlantique oriental tropical. Faune Trop ORSTOM 19:7-409

Danovaro R, Della Croce N, Eleftheriou A, Fabiano M, Papadoulou N, Smith CR, Tselepides A (1995) Meiofauna of the deep eastern Mediterranean Sea: distribution and abundance in relation to bacterial biomass, organic matter composition and other factors. Prog Oceanogr 36: 329-341

Della Croce N, Albertelli G (1995) Organismi batiali Mediterranei: ricchezza o poverta. Biol Mar Méditerr 2(2):171-175

Desbruyérès D, Geistdoerfer P, Ingram CL, Khripounoff $A$, Lagardere JP (1985) Reparation des populations de l'epibenthos carnivore. In: Laubier L, Monniot C (eds) Peuplements profounds du Golfe de Gasgogne Campagnes BIOGAS. IFREMER, Brest, p 233-252

Dugdale RC, Wilkerson FP (1988) Nutrient sources and primary production in the eastern Mediterranean Sea. Oceanol Acta 9:178-184

Ebert DA (1994) Diet of sixgill shark, Hexanchus griseus off Southern Africa. S Afr J Mar Sci 14:213-218

Ellis DM, DeMartini EE (1995) Evaluation of a video camera technique for indexing abundances of juvenile pink snapper, Pristipomoides filamentosus and other Hawaiian insular shelf fishes. Fish Bull 93:67-77

Fredj G, Laubier L (1985) The deep Mediterranean benthos. In: Moraitou-Apostolopoulou M, Kiortsis V (eds) Mediterranean marine ecosystems. Plenum Press, New York, p 109-145

Fujita T, Inada T, Ishito Y (1995) Depth-gradient structure of the demersal fish community on the continental slope off Sendai Bay, Japan. Mar Ecol Prog Ser 118:13-23

Gage JD, Tyler PA (1991) Deep-sea biology: a natural history of organisms at the deep-sea floor. Cambridge University Press, Cambridge

Galil BS, Goren M (1994) The deep sea levantine fauna: new records and rare occurrences. Senckenb Marit 25:41-52

Gilat E, Gelman A (1984) On the sharks and fishes observed using underwater photography during a deep-water cruise in the eastern Mediterranean. Fish Res 2 257-271

Gordon JD M, Bergstad OA (1992) Species composition of demersal fish in the Rockall Trough, north-eastern Atlantic, as determined by different trawls. J Mar Biol Accoc UK 72:213-230

Haedrich RL, Merrett N (1990) Little evidence for faunal zonation of fish communities in deep-sea demersal fish faunas. Prog Oceanogr 24:239-250

Hecker B (1990) Variation in megafaunal assemblages on the continental margin south of New England. Deep-Sea Res $37: 37-57$

Henriques C, Priede IG, Bagley PM (2002) Baited camera observations of deep-sea demersal fishes of the northeast Atlantic Ocean at $15-28^{\circ} \mathrm{N}$ off West Africa. Mar Biol 141: 307-314

Ignatiades L (1998) The productive and optical status of the oligotrophic waters of the southern Aegean (Cretan Sea), eastern Mediterranean. J Plankton Res 20:985-995

Jones EG, Collins MA, Bagley PM, Addison S, Priede IG (1998) The fate of cetacean carcasses in the deep sea: observations on consumption rates and succession of scavenging species in the abyssal north-east Atlantic Ocean. Proc R Soc Ser B 265:1119-1127

Kallianiotis A, Sophronidis K, Vidoris P, Tselepides A (2000) Demersal fish and megafaunal assemblages on the Cretan continental shelf and slope (NE Mediterranean): seasonal variation in species density, biomass and diversity. 46: $429-455$
Karakassis I, Eleftheriou A (1998) The Continental Shelf of Crete: the benthic environment. PSZN I: Mar Ecol 19:263-277

Klausewitz W (1989) Deepsea and deep water fish of the eastern Mediterranean, collected during the MeteorExpedition 1987. Senckenb Marit 20:251-263

Koukouras A, Kitsos MS, Tselepides A (2000) The genera Chaceon Manning, Holthuis and Geryon Krøyer (Decapoda, Geryonidae) in the eastern Mediterranean. Crustaceana 73:107-114

Krom MD, Brenner S, Kress N, Neori A, Gordon LI (1992) Nutrient dynamics and production in a warm-core eddy from the eastern Mediterranean. Deep-Sea Res A 39: $467-480$

Macpherson E (1980) Regimen alimentaire de Galeus melastomus Rafinesque, 1810, Etmopterus spinax (L., 1758) et Scymnorhinus licha (Bonnaterre, 1788) en Méditerranée occidentale. Vie Milieu 30:139-148

Macpherson E, Duarte CM (1991) Bathymetric trends in demersal fish size - is there a general relationship? Mar Ecol Prog Ser 71:103-112

Mauchline J, Gordon JDM (1984) Diets and bathymetric distributions of the macrourid fish of the Rockall Trough, northeastern Atlantic Ocean. Mar Biol 81:107-121

Merrett NR, Haedrich RL (1997) Deep-Sea demersal fish and fisheries. Chapman \& Hall, London

Merrett NR, Marshall NB (1981) Observations on the ecology of deep-sea bottom-living fishes collected off northwest Africa $\left(08^{\circ}-27^{\circ} \mathrm{N}\right)$. Prog Oceanogr 9:185-244

Moranta J, Stefanescu C, Massuti E, Morales-Nin B, Lloris D (1998) Fish community structure and depth-related trends on the continental slope of the Balearic Islands (Algerian basin, western Mediterranean). Mar Ecol Prog Ser 171: $247-259$

Pérès JM (1982) Major benthic assemblages. In: Kinne O (ed) Marine ecology. John Wiley, Chichester, p 373-522

Priede IG, Bagley PM (2000) In situ studies on deep sea demersal fishes using autonomous unmanned lander platforms. Oceanogr Mar Biol Annu Rev 38:357-392

Priede IG, Merrett NR (1996) Estimation of abundance of abyssal demersal fishes; a comparison of data from trawls and baited cameras. J Fish Biol 49(Suppl A):207-216

Priede IG, Merrett NR (1998) The relationship between numbers of fish attracted to baited cameras and population density: studies on demersal grenadiers Coryphaenoides (Nematonurus) armatus in the abyssal NE Atlantic. Fish Res 36:133-137

Priede IG, Bagley PM, Smith A, Creasey S, Merrett NR (1994) Scavenging deep demersal fishes of the Porcupine Seabight, north-east Atlantic: observations by baited camera, trap and trawl. J Mar Biol Assoc UK 74:481-498

Psarra S, Tselepides A, Ingnatiades L (2000) Primary production in the oligotrophic Aegean Sea (NE Mediterranean): seasonal and interannual variability. Prog Oceanogr 46: 187-204

Sardà F, Cartes JE (1993) Relationship between size and depth in decapod crustacean populations on the deep slope in the western Mediterranean. Deep-Sea Res 40:2389-2400

Soyer J (1985) Mediterranean Sea meiobenthos. In: MoraitouApostolopoulou M, Kiortsis V (eds) Mediterranean marine ecosystems. Plenum Press, New York, p 85-108

Stefanescu C, Lloris D, Rucabado J (1992a) Deep-living demersal fishes in the Catalan Sea (western Mediteranean) below a depth of $1000 \mathrm{~m}$. J Nat Hist 26:197-213

Stefanescu C, Rucabado J, Lloris D (1992b) Depth-size trends in western Mediterranean demersal deep-sea fishes. Mar Ecol Prog Ser 81:205-213

Stefanescu C, Lloris D, Rucabado J (1993) Deep-sea fish 
assemblages in the Catalan sea (western Mediterranean) below a depth of $1000 \mathrm{~m}$. Deep-Sea Res I 40:695-707

Thurston MH, Bett BJ, Rice AL (1995) Abyssal megafaunal necrophages: latitudinal differences in the eastern North Atlantic Ocean. Int Rev Gesamten Hydrobiol 80: 267-286

Tortonese E (1960) General remarks on the Mediterranean deep-sea fishes. Bull Inst Océanogr 1167:1-14

Tselepides A, Eleftheriou A (1992) South Aegean (eastern Mediterranean) continental slope benthos: macroinfaunalenvironmental relationships. In: Rowe GT, Pariente V (eds) Deep-sea food chains and the global carbon cycle. Kluwer Academic, Dordrecht, p 45-62

Tselepides A, Polychronaki T, Akoumianaki I, Dell'Anno A, Marrale D, Pusceddu A, Danovaro R (2000a) Organic matter composition of the outer continental shelf and bathyal sediments of the Cretan Sea (NE Mediterranean). Prog Oceanogr 46:311-344

Editorial responsibility: Otto Kinne (Editor), Oldendorf/Luhe, Germany
Tselepides A, Papadopoulou N, Podaras D, Plaiti W, Koutsoubas D (2000b) Macrobenthic community structure over the continental shelf margin of Crete (south Aegean Sea, NE Mediterranean). Prog Oceanogr 46: 367-400

Whitehead PJP, Bauchot ML, Hureau JC, Nielsen J, Tortonese E (eds) (1984) Fishes of the north-eastern Atlantic and Mediterranean. UNESCO, Paris

Willis TJ, Babcock RC (2000) A baited underwater video system for the determination of relative density of carnivorous reef fish. Mar Freshw Res 51:755-763

Willis TJ, Millar RB, Babcock RC (2000) Detection of spatial variability in relative density of fishes: comparison of visual census, angling and underwater video. Mar Ecol Prog Ser 198:249-260

Yau C, Collins MA, Bagley PM, Everson I, Priede IG (2002) Scavenging megabenthos and demersal fish on the South Georgia slope. Antarct Sci 14(1):16-24

Submitted: March 21, 2002; Accepted: October 4, 2002

Proofs received from author(s): March 13, 2003 